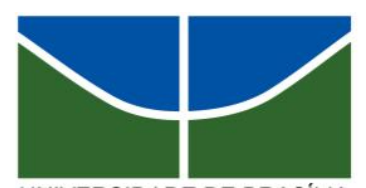

UNIVERSIDADE DE BRASÍLIA

Centro de excelência em turismo

Pós-graduação Lato Sensu

Curso de Especialização em Qualidade de Alimentos

MARCUS FERNANDO DE LIMA JACULI

\title{
AVALIAÇÃO DO USO DE AGENTES SANEANTES EM SERVIÇOS DE ALIMENTAÇÃO COLETIVA
}

BRASILIA - DF 
MARCUS FERNANDO DE LIMA JACULI

\section{AVALIAÇÃO DO USO DE AGENTES SANEANTES EM SERVIÇOS DE ALIMENTAÇÃO COLETIVA}

Monografia apresentada ao Centro de Excelência em Turismo - UnB com requisito parcial para a obtenção de titulo de Especialista em Qualidade de Alimentos.

Orientador: Prof. ${ }^{\mathrm{a}}$ MSc Lucianne Cardoso

BRASÍLIA - DF 
JACULI, Marcus Fernando de Lima.

Avaliação do uso de agentes saneantes em serviços de alimentação coletiva/ Marcus Fernando de Lima Jaculi. Brasília, 2009.

$39 f$.

Monografia de Especialização apresentada ao Curso de Especialização em Qualidade em Alimentos. Universidade de Brasília, Centro de Excelência em Turismo, 2009.

Orientador: Prof ${ }^{\mathrm{a}}$. MSc. Lucianne Cardoso.

1. Saneantes. 2. Uso e aplicação. 3. Avaliação de saneantes. 


\section{AVALIAÇÃO DO USO DE AGENTES HIGIENIZANTES EM SERVIÇOS DE ALIMENTAÇÃO COLETIVA}

Monografia apresentada ao Centro de Excelência em Turismo - CET, da Universidade de Brasília, como requisito parcial à obtenção do grau de Especialista em Qualidade em Alimentos.

Aprovado em:

Prof. $^{a}$ MSc. Lucianne Cardoso

Prof. ${ }^{a}$ MSc. Lívia de Lacerda de Oliveira Pineli

Prof. MSc. Manoel Silva Neto

BRASÍLIA - DF 


\section{DEDICATÓRIA}

Dedico este trabalho a meus pais Marcos Alves Jaculi e Maria Sirlei de Lima Jaculi, aos meus irmãos Gustavo, Ana Elise e José Victor e a minha namorada Mariana Leandro. 


\section{AGRADECIMENTOS}

Agradeço a minha orientadora Prof. ${ }^{\text {a }}$ MSc Lucianne Cardoso pela

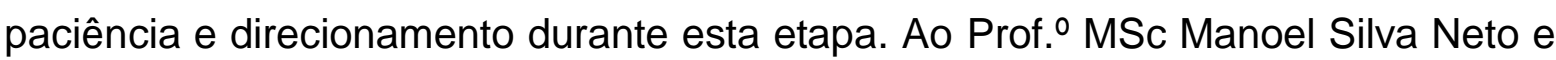
a Prof. a MSc Lívia Pineli por aceitarem com muita solicitude participar da minha banca. 


\section{RESUMO}

Com o objetivo de alcançar a qualidade sanitária dos alimentos, por exigências das legislações de saúde em vigor disposições legais são elaboradas impondo-se aos produtores e prestadores de serviços de alimentação regras que devem ser atendidas. Com isso um grande mercado surgiu especializando-se na produção de agentes higienizantes e sanitizantes para atender as empresas do setor alimentício, sejam elas indústrias alimentícias, cozinhas industriais, restaurantes e fast foods. Esta pesquisa foi classificada com um estudo de caso com caráter de avaliação informativa, pois teve como objetivo avaliar o conhecimento de responsáveis técnicos a respeito de agentes saneantes utilizados em serviços de alimentação coletiva no Plano Piloto, fez-se uso de um questionário subjetivo onde os entrevistados ficaram livres para responder da forma que achassem melhor e uma adaptação do check list da RDC 216 de 2004 aproveitando somente 0 que diz respeito à higienização e sanitização dos estabelecimentos.

Palavras-chave: Saneantes, Uso e aplicação, Avaliação de saneantes. 


\section{SUMÁRIO}

RESUMO

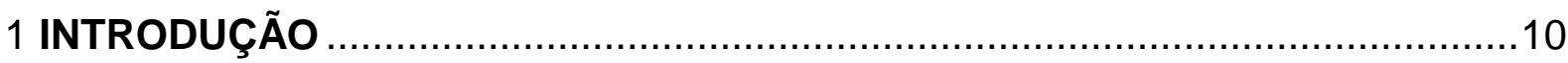

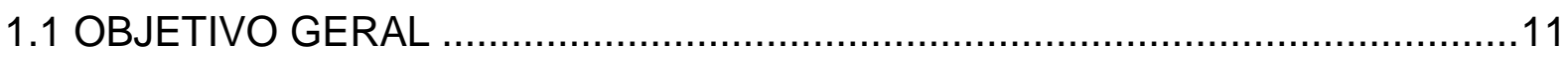

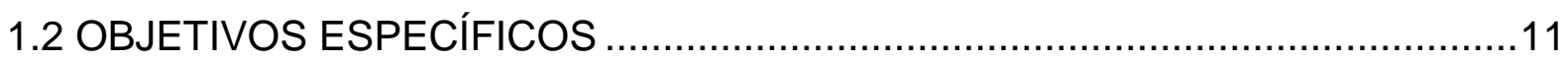

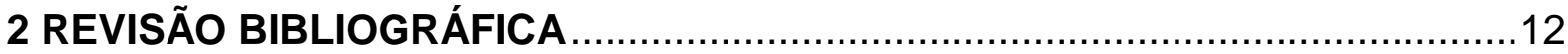

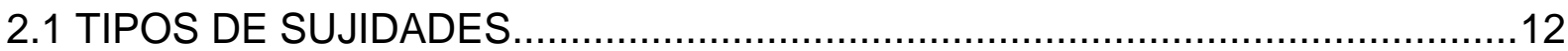

2.2 SUPERFÍCIES UTILIZADAS PARA CONTATO COM ALIMENTO ....................13

2.3 FUNDAMENTOS DA HIGIENIZAÇÃO .................................................. 14

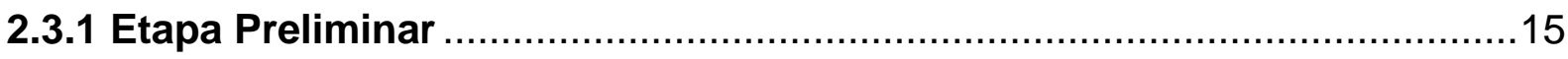

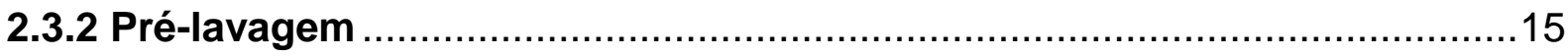

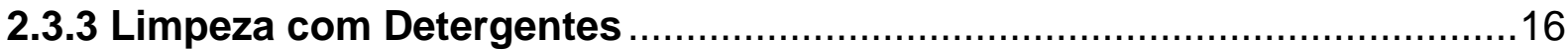

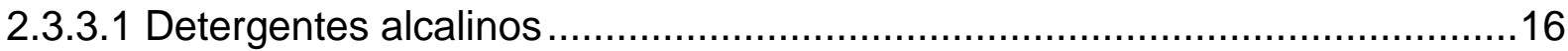

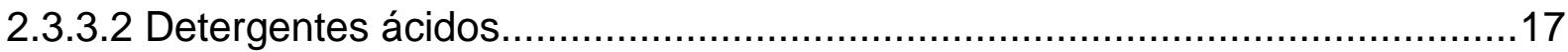

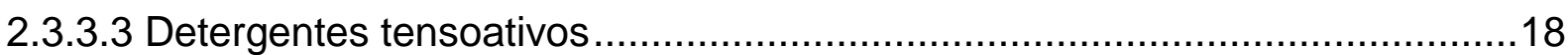

2.3.3.3.1 Detergentes tensoativos aniônicos ................................................... 18

2.3.3.3.2 Detergentes tensoativos catiônicos ................................................18

2.3.3.3.3 Detergentes tensoativos não-iônicos..................................................19

2.3.3.3.4 Anfóteros ................................................................................. 19

2.3.3.4 Formulação de detergentes na indústria de alimentos ..............................20

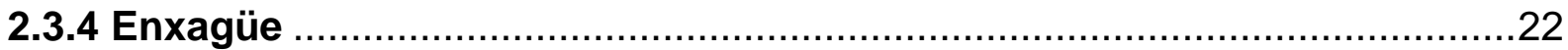

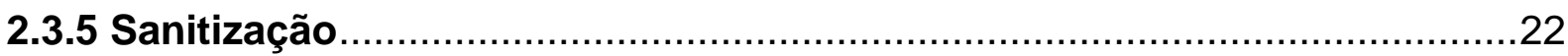

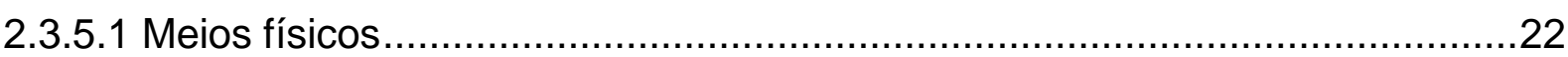

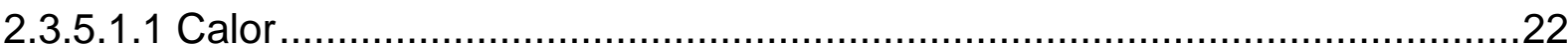

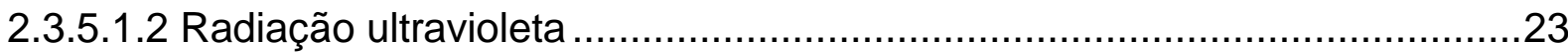

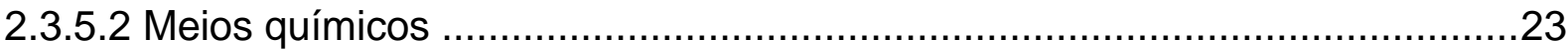

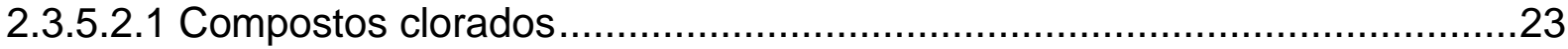

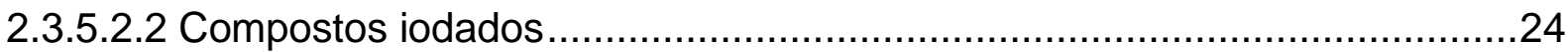

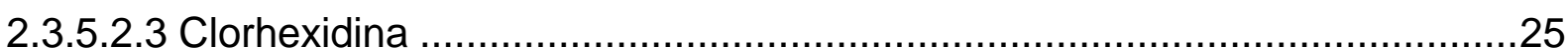

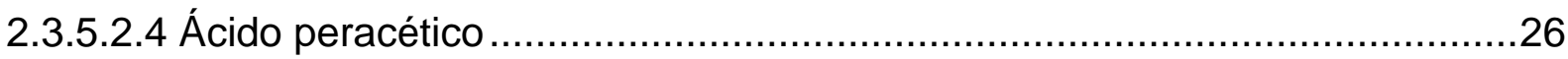

2.3.5.2.5 Compostos quaternário de amônio (CQA) ..........................................26

2.4 AVALIAÇÃO DE EFICIÊNCIA DOS SANITIZANTES ...................................27

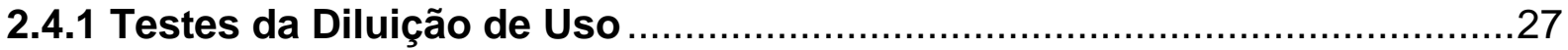




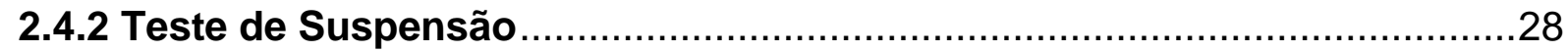

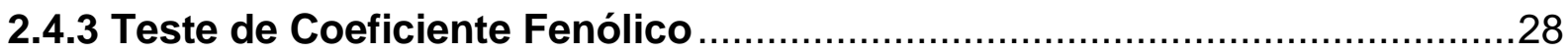

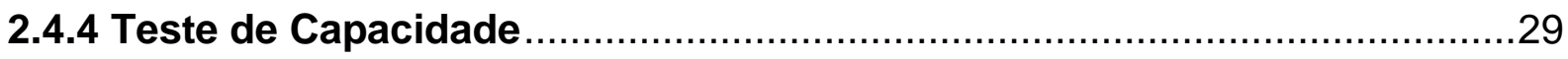

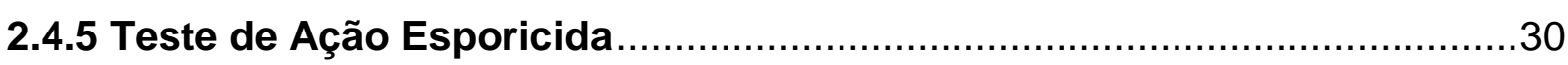

3 METODOLOGIA

4 RESULTADOS E DISCUSSÃO

5 CONCLUSÃO

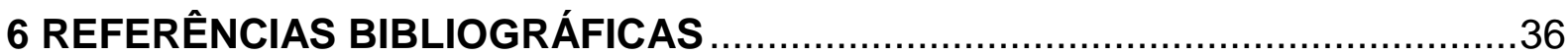

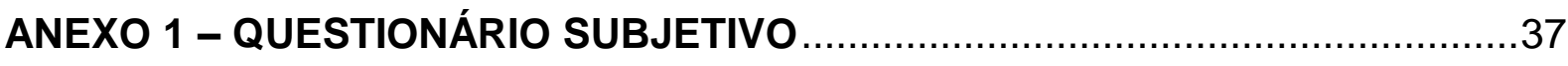

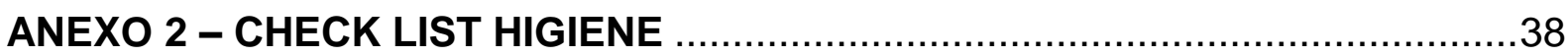




\section{INTRODUÇÃO}

Questão de grande importância na atualidade é a qualidade higiênicosanitária dos alimentos ofertados a população.

A qualidade sanitária do alimento depende do controle exercido sobre os perigos químicos, físicos e biológicos, que permeiam todas as etapas da cadeia alimentar, iniciada na produção primária e finalizada no consumo.

Com o objetivo de alcançar a qualidade sanitária dos alimentos, por exigências das legislações de saúde em vigor, como também determinações de acordos estabelecidos no comércio internacional, disposições legais são elaboradas impondo-se aos produtores e prestadores de serviços de alimentação regras que devem ser atendidas.

Para assegurar a saúde do consumidor e melhorar as condições higiênico-sanitárias na preparação de alimentos e adequar à ação da Vigilância Sanitária, o Ministério da Saúde publicou a Portaria № 1428 de 26/11/93, recomendando que seja elaborado um "Manual de Boas Práticas de Manipulação de Alimentos", baseado nas publicações técnicas da Sociedade Brasileira de Ciência e Tecnologia de Alimentos (SBCTA), Organização Mundial da Saúde (OMS) e Codex Alimentarius. Em agosto de 1997 foi publicada a Portaria N`326 de 30/07/97, que aprova o Regulamento técnico "Condições Higiênico-Sanitárias e de Boas Praticas de Fabricação para Estabelecimentos Produtores/Industrializadores de Alimentos". Em 21/10/2002 foi publicada a Resolução RDC №275 com o propósito de atualizar a legislação geral introduzindo o controle continuo das Boas Praticas de Fabricação (GMP) e os Procedimentos Operacionais Padronizados, além de promover a harmonização das ações de inspeção sanitária por meio de um instrumento genérico das ações de verificação da GMP. Observando a necessidade de constante aperfeiçoamento das ações de controle sanitário na área de alimentos visando a proteção à saúde da população e a necessidade de harmonização da ação de inspeção sanitária em serviços de alimentação, o Ministério da Saúde publicou em 2004 a Resolução RDC 216, um regulamento técnico sobre o GMP em serviços de alimentação.

Com isso um grande mercado surgiu especializando-se na produção de agentes higienizantes e sanitizantes para atender as empresas do setor alimentício, sejam elas indústrias alimentícias, cozinhas industriais, restaurantes e fast foods. 
Este trabalho tem a finalidade de avaliar o conhecimento dos responsáveis técnicos acerca dos materiais e práticas de higiene e sanitização utilizados em serviços de alimentação coletiva no Plano Piloto, Brasília - DF

\subsection{OBJETIVO GERAL}

Avaliar o conhecimento de responsáveis técnicos a respeito de agentes sanitizantes utilizados em serviços de alimentação coletiva no Plano Piloto, Brasília DF.

\subsection{OBJETIVOS ESPECÍFICOS}

Conhecer os agentes de limpeza e sanitização corretos a serem aplicados em procedimentos de higienização de serviços de alimentação.

Avaliar o conhecimento de responsáveis técnicos a respeito de agentes de limpeza e sanitização através de um questionário subjetivo.

Apontar as dificuldades encontradas por profissionais recém formados de estabelecerem os procedimentos de higienização e produtos saneantes a serem utilizados. 


\section{REVISÃO BIBLIOGRÁFICA}

\subsection{TIPOS DE SUJIDADES}

Etapas de um procedimento de higienização que normalmente são propostas para o controle higiênico de superfícies de equipamentos e utensílios levam em consideração as características de solubilidade dos resíduos de alimentos em água ou detergentes alcalinos e ácidos. A água, associada à ação mecânica, é capaz de remover com alguma facilidade resíduos de carboidratos e sais minerais monovalentes desde que não tenham sofrido ação do calor. No entanto, verifica-se a necessidade do uso de agentes alcalinos ou de tensoativos para a remoção de gordura e de ácidos para a remoção de sais minerais divalentes, como o cálcio e magnésio. Os alcalinos também são os agentes responsáveis pela remoção de resíduos de proteína. Deve-se salientar que a ação do calor torna mais difícil a remoção dos resíduos (ANDRADE, 2008). 
Quadro 1 - Solubilidade e ação do calor sobre os principais resíduos de alimentos.

\begin{tabular}{|l|l|c|l|}
\hline \multicolumn{1}{|c|}{ RESÍDUO } & \multicolumn{1}{|c|}{ SOLUBILIDADE } & $\begin{array}{l}\text { FACILIDAD } \\
\text { E DE } \\
\text { REMOÇÃO }\end{array}$ & $\begin{array}{l}\text { EFEITOS DO } \\
\text { CALOR }\end{array}$ \\
\hline Carboidrato & $\begin{array}{l}\text { Geralmente solúveis em } \\
\text { água }\end{array}$ & Fácil & Caramelização \\
\hline Gordura & $\begin{array}{l}\text { Insolúveis em água, } \\
\text { solúveis em alcalinos, } \\
\text { solúveis por tensoativos }\end{array}$ & Difícil & Polimerização \\
\hline Proteínas & $\begin{array}{l}\text { Solúveis em alcalinos } \\
\text { Solúveis em ácidos }\end{array}$ & Difícil & Desnaturação \\
\hline $\begin{array}{l}\text { Sais Minerais } \\
\text { mono-valentes } \\
\left(\mathrm{Na}^{+}, \mathrm{k}^{+}\right)\end{array}$ & Solúveis em água & Fácil & Incrustações \\
\hline $\begin{array}{l}\text { Sais Minerais } \\
\text { divalentes }\left(\mathrm{Na}^{+},\right. \\
\left.\mathrm{k}^{+}\right)\end{array}$ & Solúveis em ácidos & Difícil & Incrustações \\
\hline
\end{tabular}

Fonte: ANDRADE, 2008.

\subsection{SUPERFÍCIES UTILIZADAS PARA CONTATO COM ALIMENTO}

As superfícies comumente utilizadas para o processamento de alimentos, como aço inoxidável, polietileno, polipropileno, policarbonato, aço-carbono, mármore, madeira, teflon e vidro, permitem o crescimento microbiano, podendo originar processos de adesão microbiana e formação de biofilmes. Um processo de adesão ocorre quando a contagem de microrganismos na superfície atinge valores entre $10^{4}$ UFC.cm ${ }^{-2}$ e $10^{5}$ UFC.cm ${ }^{-2}$ (ANDRADE, 2008).

As características das principais superfícies usadas na indústria de alimentos, também utilizadas em serviços de alimentação coletiva, estão descritas na Tabela 2. 
Quadro 2 - Característica das principais superfícies utilizadas na indústria de alimentos.

\begin{tabular}{|c|c|c|}
\hline Superfícies & Características & Cuidados \\
\hline $\begin{array}{l}\text { Aço } \\
\text { Inoxidável }\end{array}$ & $\begin{array}{l}\text { Geralmente resistente à corrosão; } \\
\text { Superfície lisa e impermeável; } \\
\text { Resistente à oxidação a altas } \\
\text { temperaturas; Fácil higienização }\end{array}$ & $\begin{array}{l}\text { Certas ligas podem ser } \\
\text { corroídas por } \\
\text { halogênios }\end{array}$ \\
\hline $\begin{array}{l}\text { Aço- } \\
\text { carbono }\end{array}$ & $\begin{array}{l}\text { Corroído por detergentes ácidos e } \\
\text { alcalinos. }\end{array}$ & $\begin{array}{l}\text { Deve ser galvanizado } \\
\text { ou estanhado. Usar } \\
\text { detergente neutro na } \\
\text { higienização }\end{array}$ \\
\hline Estanho & Corroído por alcalinos e ácidos. & $\begin{array}{l}\text { Não deve entrar em } \\
\text { contato com alimentos. }\end{array}$ \\
\hline Concreto & $\begin{array}{l}\text { Danificado por alimentos ácidos e } \\
\text { agentes de limpeza. }\end{array}$ & $\begin{array}{l}\text { Deve ser denso e } \\
\text { resistente aos ácidos. }\end{array}$ \\
\hline Vidro & $\begin{array}{l}\text { Liso e impermeável. Danificado por } \\
\text { alcalinos fortes e outros agentes de } \\
\text { limpeza. }\end{array}$ & $\begin{array}{l}\text { Deve ser limpo com } \\
\text { detergente neutro ou de } \\
\text { média alcalinidade. }\end{array}$ \\
\hline Mármore & $\begin{array}{l}\text { Resistente ao calor, vulnerável a } \\
\text { desgastes físico e reações } \\
\text { químicas. }\end{array}$ & $\begin{array}{l}\text { Deve ser limpo com } \\
\text { detergente neutro ou de } \\
\text { média alcalinidade. }\end{array}$ \\
\hline Borracha & $\begin{array}{l}\text { Não deve ser porosa, não } \\
\text { esponjosa. Não ser afetada por } \\
\text { agentes alcalinos fortes. Não ser } \\
\text { atacada por solventes orgânicos e } \\
\text { ácidos fortes. }\end{array}$ & $\begin{array}{l}\text { Pode ser oxidada por } \\
\text { produtos de limpeza. } \\
\text { Possibilidade de adesão } \\
\text { bacteriana. }\end{array}$ \\
\hline Madeira & $\begin{array}{l}\text { Permeável à umidade, gordura e } \\
\text { óleo. Difícil manutenção. É } \\
\text { destruída por alcalinos fortes. }\end{array}$ & Difícil de higienizar. \\
\hline $\begin{array}{l}\text { Polipropilen } \\
\text { o }\end{array}$ & $\begin{array}{l}\text { Resistente a agentes químicos, } \\
\text { como ácidos e alcalinos }\end{array}$ & $\begin{array}{l}\text { Biodegradabilidade } \\
\text { extremamente difícil. } \\
\text { Pode ocorrer processo } \\
\text { de adesão microbiana }\end{array}$ \\
\hline
\end{tabular}

Fonte: ANDRADE, 2008.

\subsection{FUNDAMENTOS DA HIGIENIZAÇÃO}

A higienização de superfície, do ponto de vista conceitual, divide-se em duas etapas distintas: Limpeza e sanitização (ou sanificação). Na limpeza, objetivase a remoção de resíduos orgânicos e minerais - proteínas, gorduras e sais minerais e outras sujidades como terra e poeira. $\mathrm{Na}$ sanitização, procura-se eliminar microorganismos patogênicos/deteriorantes a níveis que não comprometam a qualidade higiênico-sanitária do alimento (BRASIL, 2004). 
Germano e Germano, 2003 dizem ainda que:

"Uma higienização eficiente surge da interrelação entre as energias química, mecânica e térmica, alem do tempo de duração do procedimento. Em principio, quanto maior a tempo de contato ou duração do procedimento, mais eficiente será a higienização..."

Em 2003, Rêgo e Faro subdividiram as duas etapas limpeza e sanitização em sete procedimentos. Limpeza divide-se em: i) etapa preliminar; ii) pré lavagem; iii) lavagem com detergente e; iv) enxágüe. Sanitização divide-se em: i) aplicação do sanitizantes; ii) enxágüe final e; iii) etapas finais.

\subsubsection{Etapa Preliminar}

A etapa preliminar pode envolver a colocação das partes removíveis e menores do equipamento em água, para umedecer os resíduos e remover os menos aderentes. Pode-se empregar escovas ou raspadores rígidos o bastante para despregar os resíduos, mas não tanto a ponto de danificar a superfície a ser limpa. Abrasivos como lãs de aço ou escovas metálicas não devem ser utilizados, pois riscam o equipamento e podem deixar partículas que podem gerar perigo físico para o alimento (RÊGO; FARO, 2003).

Jatos de água devem ser usados com cuidado para evitar que a sujeira deslocada não se espalhe pelo ambiente. A temperatura ideal da água para esse procedimento é em torno de $40^{\circ} \mathrm{C}$, pois quando excessivamente quente desnatura proteínas, enquanto que fria podo provocar a solidificação das gorduras. Recomenda-se que a temperatura mínima deva estar $5^{\circ} \mathrm{C}$ acima do ponto de liquefação de gorduras e a temperatura máxima dependerá do ponto de desnaturação da proteína constituinte do alimento. A ação mecânica da água é responsável pela remoção de resíduos não solúveis e diminuição da carga microbiana das superfícies (GERMANO; GERMANO, 2003).

\subsubsection{Pré-lavagem}

Visa à redução da quantidade de resíduos presentes nas superfícies dos equipamentos e utensílios utilizando-se apenas de água. Este processo remove cerca de $90 \%$ dos resíduos solúveis em água (GERMANO; GERMANO, 2003). 
Em 2003, Rêgo e Faro afirmaram que:

"Para o bom êxito da operação é necessário o emprego de água
quimicamente pura, observando-se características como dureza, ausência
de cor, sabor e odor, e contagem microbiana dentro dos padrões legais.
Dentre estas características merece destaque a dureza, que se não for
adequada pode interferir na atuação do detergente."

A condição de dureza da água é conseqüência da elevada dissolução, em água, de bicarbonatos de cálcio e de magnésio. Evangelista divide a dureza da água em dois tipos: a dureza temporal, que se deve à presença de bicarbonatos de cálcio e de magnésio. É chamada de temporal, pois os depósitos salinos que se formam nos equipamentos são facilmente removidos. O segundo tipo de dureza é a permanente, formada por sulfatos, cloretos e nitratos de cálcio e magnésio. São assim chamadas, pois formam uma crosta de difícil remoção que pode gera corrosão do equipamento.

\subsubsection{Limpeza com Detergentes}

Caracteriza-se pelo uso de detergentes em contato direto com as sujidades que tem como objetivo separá-las das superfícies a serem higienizadas, dispersá-las no solvente e prevenir nova deposição sobre as superfícies (GERMANO; GERMANO, 2003).

É a operação mais importante, e seu sucesso depende de se conhecer bem as características do detergente e de respeitar as condições de seu emprego (RÊGO; FARO, 2003).

Segundo Andrade, em 2008, é importante conhecer: i) as funções dos agentes de limpeza, como alcalinos, ácidos, tensoativos e seqüestrastes; ii) as reações físicas e, ou, químicas entre os resíduos e os detergentes durante o procedimento de higienização, como saponificação, emulsificação, molhagem, penetração, suspensão, enxaguagem, abrandamento, solubilização de minerais, solubilidade, corrosividade.

\subsubsection{Detergentes alcalinos}

Promovem o deslocamento de resíduos por emulsificação, saponificação e peptização. Removem os resíduos protéicos e gordurosos das superfícies, além de ter propriedades germicidas (GERMANO; GERMANO, 2003). 
Dentre os alcalinos, incluem-se o hidróxido de sódio, o carbonato de sódio, o metassilicato de sódio, o ortossiliciato de sódio e o sesquissilicato de sódio (ANDRADE, 2008)

- Hidróxido de sódio (soda cáustica): é o mais forte agente alcalino, de baixo custo, mas muito corrosivo. Tem excelentes propriedades saponificantes, é ótimo dissolvente e tem poder bactericida. Não pode ser usado em metais, e seu manuseio é perigoso, pois pode causar sérias queimaduras na pele (RÊGO; FARO, 2003).

- Metassilicato de sódio: é menos corrosivo e não é caustico. Quando combinado com o hidróxido de sódio suspende a ação corrosiva. Como agente de limpeza é bom, pois tem boa ação de dispersão e emulsificação, mas é de alto custo (RÊGO; FARO, 2003).

- Ortossiliciato de sódio e sesquissilicato de sódio: tem bom poder saponificante e são bastante efetivos na remoção de proteínas. São, no entanto, caros e corrosivos para alumínio (RÊGO; FARO, 2003).

- Carbonato de sódio e fosfato trissódico: são pouco corrosivos. O primeiro é usado em formulas de detergentes por sua ação tampão (estabiliza o pH), por ser barato e por precipitar os sais de cálcio e magnésio. O segundo é bom saponificante, emulsificante e dispersante além de amolecar a água (RÊGO; FARO, 2003).

\subsubsection{Detergentes ácidos}

A aplicação de agentes ácidos é efetuada quando existe a possibilidade de formação de incrustações minerais como as de água dura, depósitos calcários ocasionados por álcalis entre outros, os quais não são removidos por detergentes alcalinos. As soluções ácidas são produtos compostos de ácidos orgânicos e inorgânicos que podem ser usados individualmente ou em combinações. $O$ íon hidrogênio $\left(\mathrm{H}^{+}\right)$confere atividades aos ácidos, no entanto é extremamente corrosivo para metais, particularmente ferro galvanizado e aço inoxidável. Dentre os ácidos fortes incluem-se os inorgânicos e os orgânicos. Dentre os inorgânicos destacam-se: clorídricos, sulfúrico, nítrico e fosfórico. São exemplos de ácidos orgânicos: lático, glucônico, cítrico, tartárico, levulínico e hidroxiacético (RÊGO; FARO, 2003). 
Os ácidos orgânicos são menos corrosivos do que os inorgânicos, porém mais caros. Os ácidos muitas vezes são formulados com tensoativos para diminuir a tensão superficial da solução e melhorar o contato entre o resíduo mineral e o detergente, pois as soluções ácidas não "molham" bem as superfícies.

\subsubsection{Detergente tensoativos}

São aqueles que modificam a tensão superficial em interfaces liquidoliquido, liquido-gás, e sólido-liquido. Apresentam, geralmente, em suas fórmulas grupos polares, hidrofílicos, com afinidade pela água, e grupos não polares, lipofílicos, com afinidade por óleos e gorduras, que os tornam agentes capazes de reduzir a tensão superficial. Assim, os tensoativos são conhecidos também como detergentes sintéticos, umectantes, umedecedores, emulsificantes ou agentes de molhagem, entre outros (GERMANO; GERMANO, 2003).

Tem ainda a vantagem de serem não corrosivos, não irritantes, e fáceis de enxaguar. A dureza da água os afeta pouco o que os torna bastante solúveis. Outra vantagem é serem pouco afetados pelo pH (RÊGO; FARO, 2003). Os detergentes tensoativos são classificados em aniônicos, catiônicos, não-iônicos e anfóteros (GERMANO; GERMANO, 2003).

\subsection{Detergentes tensoativos aniônicos}

São aqueles que se dissociam em solução, sendo o íon negativo a forma ativa. A maioria dos detergentes comerciais se encontra nesta categoria. $\mathrm{Na}$ indústria de alimentos são utilizados, principalmente, os derivados de ácido sulfônico (Acil isotionatos, Aquilail sulfonados, Alquil sulfonados e sulfosuccinatos). Também são usados ésteres de ácido sulfúrico. A parte hidrofóbica é constituída pelos grupos alquil, aril e alquil-aril o que facilita a incorporação da gordura, enquanto a parte hidrofílica é constituída do sulfonato e sulfato (GERMANO; GERMANO, 2003).

\subsection{Detergentes tensoativos catiônicos}

São aqueles que, ao se dissociarem em solução, apresentam um íon positivo ativo. São compostos mais eficientes como germicidas do que como 
detergentes. Os compostos de amônio quaternário são seus principais representantes, devendo sua ação ao fat do átomo de nitrogênio possuir um par de elétrons não emparelhados, permitindo assim um ataque eletrofílico (GERMANO; GERMANO, 2003).

\subsection{Detergentes tensoativos não-iônicos}

São aqueles que não se dissociam em solução e podem ser usados juntamente com os aniônicos e catiônicos. São muito solúveis e usados como detergentes líquidos (RÊGO e FARO, 2003). São obtidos pela combinação de óxido de etileno com compostos hidrofóbicos contendo grupamentos do tipo carboxila, hidroxila ou amino, originando assim diferentes tipos de ésteres ou álcoois. Dentre eles incluem-se, álcoois etoxilados, ácidos carboxílicos etoxilados e amidas etoxiladas (GERMANO; GERMANO, 2003).

Alguns destes compostos formam pouca espuma em soluções aquosas, podendo ser usados para melhorar a molhagem dos detergentes ácidos. São compatíveis com tensoativos aniônicos e catiônicos, participando assim de diversas formulações (GERMANO; GERMANO, 2003).

\subsection{Anfóteros}

São substâncias com características de liberar carga elétrica positiva ou negativa dependendo do meio em que se encontra (GERMANO; GERMANO, 2003). São formados em geral por aminoácidos ligados a um radical alquila, dentre eles estão o acil diaquil etileno diamina e derivados e ácidos $\mathrm{N}$-alquil aminos (RÊGO; FARO, 2003).

\subsection{Agentes seqüestrantes e quelantes}

Os polifosfatos são os maiores representantes dos seqüestrantes. São usados na formulação de detergentes após a descoberta de que formam complexos solúveis com cálcio e magnésio, evitando assim a precipitação de sais que podem interferir na operação de limpeza. Compreendem uma série de complexos de fosfato de sódio, obtidos pelo aquecimento, isoladamente ou misturados com álcalis. São 
exemplos o polifosfato tetrassódico, o hexametafosfato de sódio e o tetrafosfato de sódio (GERMANO; GERMANO, 2003).

Com relação aos agentes quelantes, o ácido etilenodiamino tetra-acético (EDTA), com sais de sódio e potássio, é o mais importante, sendo capaz de remover $\mathrm{Ca}^{++}, \mathrm{Mg}^{++}$e $\mathrm{Fe}^{++}$de soluções com efeito similar aos polifosfatos. (GERMANO; GERMANO, 2003).

2.3.3.4 Formulação de detergentes na indústria de alimentos

Para se obter um bom efeito de higienização são misturados diferentes substancias químicas em forma líquida ou em pó. Em geral a formulação tem um álcali para dissolver gorduras, um tensoativo para melhorar a penetração da água a dispersão e o enxágüe e um seqüestrante para combater a dureza da água (RÊGO; FARO, 2003). Quanto mais eficiente se deseja tornar a higienização, mais complicada é a composição do produto a ser usado. A seguir, algumas sugestões de formulações para determinadas aplicações na indústria de alimentos. 
Quadro 3: Sugestão de formulação de detergentes para diversas aplicações:

\begin{tabular}{|c|c|}
\hline \multicolumn{2}{|c|}{ Detergente para higienização de mãos } \\
\hline Agentes químicos & $\begin{array}{c}\text { Concentração } \\
\%\end{array}$ \\
\hline $\begin{array}{l}\text { Dodecilbenzeno sulfonado de sódio (LAS) } \\
40 \%\end{array}$ & 10 \\
\hline Tensoativo não iônico & 4 \\
\hline Tripolifosfato de sódio & 25 \\
\hline Metassilicato de sódio & 10 \\
\hline Borax ou sulfato de sódio & 51 \\
\hline \multicolumn{2}{|c|}{ Detergente para higienização de garrafas } \\
\hline Agentes químicos & $\begin{array}{c}\text { Concentração } \\
\%\end{array}$ \\
\hline Hidróxido de sódio & 68 \\
\hline Fosfato de trissódio & 4 \\
\hline Carbonato de sódio & 14 \\
\hline Pirofosfato tetrassódico & 8 \\
\hline Metassilicato de sódio & 6 \\
\hline \multicolumn{2}{|c|}{ Detergente para Limpeza CIP (Clening in Place) } \\
\hline Agentes químicos & $\begin{array}{c}\text { Concentração } \\
\%\end{array}$ \\
\hline Gluconato de sódio & 5 \\
\hline Hidróxido de sódio & 95 \\
\hline \multicolumn{2}{|c|}{ Detergente para higienização de tubulações de aço inoxidável } \\
\hline Agentes químicos & $\begin{array}{c}\text { Concentração } \\
\%\end{array}$ \\
\hline Tensoativo não iônico & 3 \\
\hline Tripolifosfato de sódio & 25 \\
\hline Metassilicato de sódio & 10 \\
\hline Carbonato de sódio & 30 \\
\hline Sulfato de sódio & 32 \\
\hline \multicolumn{2}{|c|}{ Detergente para remoção de minerais } \\
\hline Agentes químicos & $\begin{array}{c}\text { Concentração } \\
\%\end{array}$ \\
\hline Tensoativo não iônico & 0,3 \\
\hline Ácido fosfórico & 31 \\
\hline Água & 68,7 \\
\hline
\end{tabular}

Fonte: TAMPLIM apud ANDRADE e MACÉDO apud GERMANO; GERMANO, 2003. 


\subsubsection{Enxágüe}

Após a lavagem com detergentes, os equipamentos devem se enxaguados para promover a remoção completa de resíduos suspensos e traços dos componentes de limpeza. Para garantir uma completa remoção de detergentes alcalinos recomenda-se a aplicação de algumas gotas de fenolftaleína para avaliar a eficácia do enxágüe, devendo a água permanecer incolor indicando $\mathrm{pH}$ inferior a 8,3. A remoção de detergentes ácidos pode ser avaliada usando-se como indicador o metilorange que neste caso deixará a água com uma coloração amarelada indicando pH próximo da neutralidade (GERMANO; GERMANO, 2003).

\subsubsection{Sanitização}

É a ultima e mais importante etapa do processo de higienização. Tem por objetivo a eliminação de microrganismos patogênicos e a redução de deteriorantes, a níveis seguros, nas superfícies de equipamentos, utensílios e instalações. Um equipamento que não tenha sido adequadamente limpo não poderá ser sanitizado com eficiência, pois resíduos remanescentes protegerão os microrganismos da ação do agente sanitizante, que por si só não é capaz de corrigir falhas das etapas anteriores. A sanitização poder ser efetuada por meios físicos e químicos, sendo a ultima a mais utilizada (GERMANO; GERMANO, 2003).

\subsubsection{Meios físicos}

\subsection{Calor}

Consiste na aplicação direta de fluido aquecido sobre superfície de equipamentos e utensílios. Pode ser realizada pela exposição ao ar quente a uma temperatura de $90^{\circ} \mathrm{C}$ por 20 minutos, exposição à água quente a $77^{\circ} \mathrm{C}$ por 15 minutos, ou ainda $93^{\circ} \mathrm{C}$ por 5 minutos, ou aplicação direta de vapor durante 1 minuto (GERMANO; GERMANO, 2003). 


\subsection{Radiação ultravioleta}

Usada para a redução de microrganismos em área de processamento, laboratórios e câmaras. Encontram-se no mercado dois tipos de lâmpadas para este procedimento, lâmpadas de argônio-mercúrio, indicadas para pequenas instalações e lâmpadas de mercúrio-quartzo, recomendadas para instalações maiores. Estas lâmpadas emitem radiação na faixa de comprimento de onda de 900 a $3800 \AA$, sendo a zona mais letal próximo a 2600 Á. Porém são de custo elevado devido ao alto consumo de energia elétrica e sua eficiência decresce com o tempo de uso, devendo ser substituída a cada 6 meses (GERMANO; GERMANO, 2003).

\subsubsection{Meios químicos}

Por razões econômicas são os mais utilizados, destacando-se o uso dos compostos clorados, iodados e quaternários de amônio.

\subsection{Compostos clorados}

O cloro é o sanitizante mais usado e atuam liberando íons $\mathrm{OCl}^{-}$em solução, que é o agente bactericida (RÊGO; FARO, 2003). Atua combinando-se a radicais oxidáveis, principalmente -SH de enzimas (GERMANO; GERMANO, 2003). Para minimizar a instabilidade dos compostos clorados, sobre tudo dos inorgânicos, eles devem ser armazenados em recipientes escuros, bem fechados, em locais bem ventilados e de temperaturas não elevadas para que não haja diminuição do teor de cloro residual. O contato com a luz decompõe os produtos clorados e a temperatura elevada provoca sua volatilização (GERMANO; GERMANO, 2003).

De modo geral, recomenda-se após a aplicação de compostos clorados a uma concentração acima de 200ppm, um enxágüe final com água potável para que o cloro residual não reaja com a matéria orgânica dos alimentos (GERMANO; GERMANO, 2003).

Os produtos clorados, como sais de hipoclorito, constituem o grupo de compostos clorados mais utilizados. No entanto nos últimos anos tem existido certa preocupação quanto ao uso do hipoclorito e dos demais sais de cloro considerados 
precursores na formação de cloraminas orgânicas, estas prejudiciais à saúde devido ao seu alto potencial carcinogênico (McNEAL ${ }^{1}$, et al, 2007 apud SREBERNICH, 2007).

O dióxido de cloro, porém, vem recebendo atenção especial, pois embora seja um derivado do cloro, ele gera quantidade insignificante de subprodutos (trihalometanos) não se obtendo a formação de cloraminas, e sendo os fenóis oxidados a formas mais simples, caracterizando-se assim como um produto de baixo potencial carcinogênico (ANDRADE; MACEDO, 1996).

Além disso, o dióxido de cloro é um agente oxidante forte, que na maioria das vezes reage por meio do mecanismo de transferência de elétrons atacando a membrana celular, penetrando, desidratando, e por último, oxidando os componentes internos da célula microbiana sem, no entanto, causar ação tóxica como a maioria dos compostos de cloro (SREBERNICH, 2007).

Em seus estudos Srebernich, 2007, determinou que o tratamento com dióxido de cloro a 50 ppm/10 minutos mostrou-se mais eficiente ou praticamente no mesmo nível de redução de coliformes totais, E. coli e fungos que o hipoclorito de sódio a 120 ppm. Para se obter resultado superior ao $\mathrm{NaOCl}$ seria conveniente trabalhar com concentração superior a 50 ppm, provavelmente na faixa de 60 ppm/10 minutos

\subsubsection{Compostos iodados}

A ação bactericida dos compostos iodados deve-se, principalmente, ao $\mathrm{I}_{2}$ liberados pelas soluções aquosas e pelos complexos com agentes tensoativos. Verifica-se que o iodo é eficiente sobre células bacterianas, sejam Gram positivas ou negativas e é modestamente eficiente sobre fungos, leveduras e vírus. Pressupõe-se que $\circ \mathrm{I}_{2}$ penetre a parede celular ocasionando a destruição da estrutura protéica e inibiria o sistema enzimático por meio da oxidação do aminoácido tirosina, formando diiodotirosina. Esta reação alteraria a estrutura da enzima e assim sua atividade (GERMANO; GERMANO, 2003).

\footnotetext{
${ }^{1}$ McNEAL, T. P.; HOLLIFIELD, H. C.; DIACHENKO, G. W. Survey of trihalomethanes and other volatile chemical contaminants in processed foods by purge-and-trape capillary gas chromatography with mass selective detection. Journal of the Association of Official Analytical Chemistry International, v. 78, n. 2, p. 391-397, 1995.
} 
Porém a utilização do iodo para desinfecção de cozinhas tem sido muito discutida ultimamente. Desde 1979, a Food and Nutrition Board fixou a RDA (Recomended Dietary Allowances) do iodo em $150 \mathrm{mcg} / \mathrm{dia}$, ou seja, os níveis de ingestão de nutrientes essenciais, adequados para suprir as necessidade das pessoas sadias. Tem-se observado anomalias orgânicas em relação ao consumo de iodo. O consumo diário de aproximadamente $200 \mathrm{mcg}$ de iodo causa uma rápida e transitória inibição de síntese de tiroxina e em pessoas normais pode ou não haver uma adaptação, mas em pessoas com hipotiroidismo, as vezes, pode acarretar aumento do tamanho da glândula, ocorrendo bócio. A ingestão elevada de iodo (200mcg/dia), durante algumas semanas, pode gerar um quadro de hipertiroidismo em pessoas normais, principalmente em idosos (SILVA Jr, 2007).

Estudos atuais relatados pelo FDA (USA) indicam que na dieta normal diária já estamos ingerindo quantidade de iodo acima do normal, sendo assim, devese tomar muito cuidado com qualquer resíduo de iodo em equipamentos e utensílios (SILVA Jr, 2007).

\subsection{Clorhexidina}

A clorhexidina pode ser usada como desinfetante de anti-séptico, na forma hídrica, alcoólica ou como sabão. É um produto estável, não volátil, atóxico, não corrosivo, não é inativado por matéria orgânica. É ativo contra bactérias Grannegativas, Gram-positivas, esporos bacterianos e fungos (SILVA Jr, 2007).

É uma base branca, nas formas de diacetato e diidro-cloreto, que são solúveis em água a $20^{\circ} \mathrm{C}$, de $1,9 \%$ a $0,06 \%$. A clorhexidina pode ser inativada por precipitação por sais minerais, inclusive por aquele que compõem a dureza da água. As soluções aquosas deste sanitizante não possuem cor nem odor, mas tem pouco efeito de molhagem, por isso podem ser utilizados tensoativos catiônicos e não iônicos para melhorar esta característica (GERMANO; GERMANO, 2003).

O mecanismo de ação da clorhexidina consiste na rápida absorção pelas células bacterianas, resultando em diversas modificações citológicas que afetam a permeabilidade. A quantidade do agente químico absorvida é proporcional à sua concentração, à densidade da célula bacteriana e à composição e $\mathrm{pH}$ do meio (GERMANO; GERMANO, 2003). 
Segundo Mazzola et al, em seu estudo para a determinação do tempo de redução decimal (valor $\mathrm{D}$ ) de agentes sanitizantes, observou que algumas cepas vegetativas mostram uma melhor resistência a uma solução de digluconato de clorhexidina a $0,4 \%$, sendo $S$. aureus ( $D=5,9 \mathrm{~min}$ ) e $E$. coli ( $D=3,0 \mathrm{~min})$. Cepas de B. stearothermophilus expostas a uma solução de $2 \%$ de clorhexidina apresentaram valor $\mathrm{D}$ de $9,1 \mathrm{~min}$.

\subsubsection{4 Ácido peracético}

É o principio ativo de diversos sanitizantes comerciais. Estes produtos são constituídos de uma mistura de ácido peracético, peróxido de hidrogênio, ácido acético e um veiculo estabilizante (GERMANO; GERMANO, 2003).

Trata-se de um excelente sanitizante pela grande capacidade de oxidação dos componentes celulares dos microrganismos, tendo uma rápida ação a baixas concentrações sobre um amplo espectro de microrganismos. É esporicida em baixas temperaturas e continua efetivo na presença de material orgânico sendo, portanto, um biocida efetivo sem residual tóxico (SREBERNICH, 2007).

O ácido peracético é irritante para a pele e para as mucosas, havendo necessidade de cuidados especiais no manuseio do produto concentrado como roupas protetoras, luvas de PVC e proteção ocular. Quando da aplicação deve-se tomar precauções para evitar sua ação corrosiva, pois ataca ferro, cobre, níquel, titânio, cromo, prata, zinco, alumínio e suas respectivas ligas (GERMANO; GERMANO, 2003).

Utilizando-se do ácido peracético Srebernich, 2007, identificou que o tratamento com 100 ppm/15 minutos apresentou resultado superior ao tratamento com $\mathrm{NaOCl}$ a 120 ppm, porém o tratamento com 80 ppm/5 minutos já ofereceu resultado igual ou superior ao do hipoclorito.

\subsection{Compostos quaternário de amônio (CQA)}

São compostos tensoativos, catiônicos que apresentam pouca atividade como detergentes, mas boa atividade germicida. Vários mecanismos de ação associados dão origem à atividade germicida a estes compostos, tais como a inibição enzimática, a desnaturação protéica e a lesão da membrana citoplasmática 
com o conseqüente extravasamento dos constituintes celulares (GERMANO; GERMANO, 2003).

Os CQA formam um filme bacteriostático sobre as superfícies, mas atuam com menos eficiência sobre bactérias Gram-negativas (coliformes e psicrotróficos) do que sobre as Gram-positivas (Staphylococcus spp e Streptococcus spp). A atividade sobre bactérias Gram-negativas pode ser aumentada com o uso de EDTA, pois este atua como quelante para algumas estruturas da parede celular, possibilitando a penetração do composto na membrana (GERMANO; GERMANO, 2003).

\subsection{AVALIAÇÃO DE EFICIÊNCIA DOS SANITIZANTES}

A avaliação da eficiência dos sanitizantes é bastante complexa, principalmente em razão dos inúmeros fatores que poderão afeta-lá. Assim, a natureza e tipo de superfícies tratadas, a concentração e natureza dos resíduos, o tipo de microbiota contaminante na superfície, a concentração e o período de contato do sanitizante com a superfície são apenas algumas das variáveis que poderão afetar, em menor ou maior grau, a eficiência dos sanitizantes (ANDRADE, 2008).

As comprovações da eficiência microbiológica dos sanitizantes químicos são necessárias, e uma das formas de se confirmar isso é por meio de testes laboratoriais, como os de diluição de uso, de capacidade, de coeficiente fenólico, teste esporicida e de suspensão. Deve-se frisar que apenas a determinação do princípio ativo dos produtos sanitizantes comerciais ou de suas soluções diluídas para uso rotineiro no procedimento de higienização não é suficiente para definir a atividade antimicrobiana, pois produtos que originam soluções sanitizantes com a mesma concentração de principio ativo poderão apresentar eficiência diferente sobre os microrganismos (ANDRADE, 2008).

\subsubsection{Teste da Diluição de Uso}

A diluição de uso, um teste laboratorial amplamente aceito, reconhecido como rigoroso e bem padronizado, tem como principais objetivos determinar a maior diluição do sanitizante que ainda apresenta diluição eficiência bactericida e avaliar 
as concentrações de sanitizante recomendadas pelos fabricantes (ANDRADE, 2008).

Esse teste consiste em submeter células de Salmonella choleraesuis ATCC 10708, de Staphylococcus aureus ATCC 6538 e de Pseudomonas aeruginosas ATCC 15442, aderidas às superfícies de cilindros de aço inoxidável, à ação de soluções de sanitizantes, sendo aprovadas aquelas que destruírem o organismo-teste aderido em 59 cilindros de 60 avaliações, após 10 minutos de contato à temperatura de $20^{\circ} \mathrm{C}$ (ANDRADE, 2008).

\subsubsection{Teste de Suspensão}

O teste de suspensão avalia a eficiência de sanitizantes na redução de uma população microbiana em suspensão, sob condições praticas de uso, e é recomendado pela Association of Official Analitycal Chemists (AOAC) para avaliar sanitizantes empregados em superfícies não porosas, previamente limpas, que entram em contato com alimentos (ANDRADE, 2008).

Os resultados são apresentados na forma de número de reduções decimais (RD) na população microbiana de Escherichia coli ATCC 11229 e de Staphylococcus aureus ATCC 6538, levando em conta o tempo de exposição e a concentração do sanitizante.

A RD é a diferença entre o logaritmo decimal do total de microrganismos na suspensão microbiana e o logaritmo decimal de sobreviventes após o contato com a solução sanitizante. Será aprovado o sanitizante que assegurar redução decimal superior ou igual a 5 , que corresponde a uma redução de cinco ciclos logarítmicos ou 99,999\%, na população microbiana, após 30 segundos de exposição a $20^{\circ} \mathrm{C}$ (ANDRADE, 2008).

\subsubsection{Teste de Coeficiente Fenólico}

O teste de coeficiente fenólico foi, praticamente, o primeiro a ser desenvolvido com o processo de avaliar a eficiência dos sanitizantes. A metodologia deste teste tem recebido várias propostas de modificações ao longo do tempo, permanecendo em todos eles o fundamento básico original: a comparação da eficiência de sanitizante contra uma solução-padrão de fenol, ambas atuando sobre 
células vegetativas de bactérias. É um método oficial preconizado pela AOAC (ANDRADE, 2008).

O teste é realizado sob condições rigidamente definidas. A AOAC recomenda como organismos de teste as culturas-teste de Pseudomonas aeruginosa ATCC 15442, Salmonella typhi ATCC 6538. Na Tabela 4, encontram-se resumidos os fundamentos, a interpretação dos resultados e as limitações do teste do coeficiente fenólico (ANDRADE, 2008).

Quadro 4 - Fundamento, interpretação dos resultados e limitações do teste do coeficiente fenólico

\begin{tabular}{|l|l|}
\hline \multicolumn{2}{|c|}{ Testes do coeficiente fenólico } \\
\hline Fundamento & $\begin{array}{l}\text { Compara a eficiência do sanitizante contra uma solução de } \\
\text { fenol }\end{array}$ \\
\hline $\begin{array}{l}\text { Interpretação } \\
\text { dos Resultados }\end{array}$ & $\begin{array}{l}\text { Determinação do coeficiente fenólico } \\
\text { Diluição de uso }\end{array}$ \\
\hline Limitações & $\begin{array}{l}\text { Pouco reprodutível } \\
\text { Possibilidade de sobrevivência de células muito resistentes } \\
\text { Não permite simular condições usuais da indústria de } \\
\text { alimentos } \\
\\
\text { Os resultados devem ser confirmados por outros testes } \\
\text { Sua precisão é discutível. }\end{array}$ \\
\hline
\end{tabular}

Fonte: ANDRADE, 2008.

\subsubsection{Teste de Capacidade}

O teste de capacidade é recomendado principalmente para avaliar a possibilidade de reutilização de sanitizantes ou detergentes-sanitizantes, após consecutivos contatos com microrganismos e matéria orgânica. Consiste em adicionar determinada quantidade de inóculo à solução sanitizante a ser testado e, após o contato desejado, normalmente 1 minuto, transferir para meio de subcultivo com inativador do agente químico. Depois de 30 segundos da primeira exposição, adicionar outra quantidade de inóculo na mesma solução sanitizante, inativando-se após o tempo de contato desejado. O processo se repete, atingindo-se 10 adições consecutivas. Será aprovada no teste a diluição que apresentar crescimento microbiano em no máximo quatro tubos de subcultivo (ANDRADE, 2008). 


\subsubsection{Teste de Ação Esporicida}

O teste esporicida é aplicável a substâncias químicas líquidas e gasosas, por meio do qual se constata ausência ou a presença da atividade esporicida. Consiste em submeter esporos de Bacillus subtilis ATCC19659 e Clostridium sporogenes ATCC 1584, previamente secos e aderidos a cilindros de porcelana. Para ser classificada como esporicida, o agente químico na concentração, no tempo de contato recomentado e em outras condições avaliadas, deve eliminar os esporos em 118 dos 120 cilindros testados, metade deles com Bacillus subtilis e a outra metade por Clostridium sporogenes (ANDRADE, 2008). 


\section{METODOLOGIA}

A delineação da hipótese a ser abordada ocorreu pelo método indutivo. Observou-se a necessidade de avaliar o conhecimento dos responsáveis técnicos de serviços de alimentação coletiva do Plano Piloto, Brasília - DF, sobre sanitização de equipamentos e utensílios e os meios utilizados para tal finalidade.

Para formação do embasamento teórico desta pesquisa fez-se uso de literatura específica disponível na Instituição a qual pertence o autor deste estudo, bem como em bibliotecas de outras instituições de ensino superior do Distrito Federal.

Esta pesquisa foi classificada com um estudo de caso com caráter de avaliação informativa, pois teve como objetivo avaliar o conhecimento de responsáveis técnicos a respeito de agentes saneantes utilizados em serviços de alimentação coletiva no Plano Piloto, fez-se uso de um questionário subjetivo onde os entrevistados ficaram livres para responder da forma que achassem melhor e uma adaptação do check list da RDC 216 de 2004 aproveitando somente o que diz respeito à higienização e sanitização dos estabelecimentos, conforme pode ser observado nos anexos 1 e 2 . 


\section{RESULTADOS E DISCUSSÃO}

Foram visitados dez estabelecimentos de serviços de alimentação coletiva do Plano Piloto, Brasília - DF, que tivessem responsável técnico e manual de boas práticas de fabricação.

Foram obtidos os seguintes resultados a partir da aplicação do questionário subjetivo:

A respeito de como foi estabelecido o tipo de saneante a ser utilizado em cada procedimento:

- 90\% dos entrevistados disseram ter buscado auxílio de literatura específica para estabelecer o tipo de saneante a ser utilizado nos procedimentos de higienização.

- Destes, 20\% disseram ter consultado sites da ANVISA e do Ministério da Saúde para estabelecer o tipo de saneante a ser utilizado.

- $10 \%$ disseram ter estabelecido os saneantes de acordo com as sujidades e microrganismos a serem combatidos.

Quando questionados sobre a influência de conhecimentos prévios sobre princípios para a escolha de saneantes:

- 100\% disseram que conhecimentos prévios adquiridos na graduação não foram suficientes para a escolha dos saneantes. Foi unânime entre os entrevistados que durante a graduação as informações transmitidas são muito superficiais dificultando o trabalho dos mesmos quando entram no mercado de trabalho.

- $100 \%$ dos entrevistados informaram que utilizaram de literatura específica e artigos científicos como fonte de pesquisa para estabelecer os saneantes utilizados nos procedimentos operacionais. Destes, $40 \%$ informaram que também utilizaram os sites da ANVISA e do Ministério da Saúde como fonte de informações para determinar quais saneantes seriam utilizados.

Sobre o questionamento dos critérios para a seleção dos saneantes utilizados obteve-se as seguintes respostas:

- $70 \%$ dos entrevistados disseram que o principio ativo indicado por literatura especifica foi o principal critério.

- 90\% disseram que o critério para a escolha foi o de o produto ser registrado no Ministério da Saúde. 
- 30\% disseram ter realizado teste para determinar a eficiência de diferentes produtos com o mesmo principio ativo, para assim determinar qual teria 0 maior custo beneficio.

Sobre a freqüência de higienização, $100 \%$ dos entrevistados disseram que os procedimentos de higienização são realizados sempre que necessário e no final da produção conforme é determinado pela RDC 216 de 2004.

Quando questionados sobre como é feita a diluição, $100 \%$ dos entrevistados disseram utilizar a diluição estabelecida pelo fabricante conforme é recomendado pela RDC 216 de 2004.

Foram obtidos os seguintes resultados a partir da aplicação do check list adaptado da RDC 216 de 2004:

- Somente um estabelecimento manteve $100 \%$ dos requisitos da RDC 216;

- Um estabelecimento apresentou 95\% de conformidades;

- Dois estabelecimentos apresentaram $90 \%$ de conformidade;

- Cinco estabelecimentos apresentaram $85 \%$ de conformidade;

- e um estabelecimento apresentou $80 \%$ de conformidade.

$\mathrm{Na}$ tabela abaixo é possível visualizar quais os itens do check list apresentaram não conformidades. 
Quadro 5: Não conformidades apresentadas nos estabelecimentos.

\begin{tabular}{|l|c|}
\hline Item do check list & $\begin{array}{l}\text { Estabelecimentos } \\
\text { que apresentaram } \\
\text { não } \\
\text { conformidade. }\end{array}$ \\
\hline $\begin{array}{l}1.1 \text { - As instalações, os equipamentos, os móveis e os } \\
\text { utensílios são mantidos em condições higiênico-sanitárias } \\
\text { apropriadas. }\end{array}$ & 1 \\
\hline $\begin{array}{l}1.2 \text { - As operações de higienização são realizadas por } \\
\text { funcionários comprovadamente capacitados e com } \\
\text { freqüência que garanta a manutenção dessas condições e } \\
\text { minimize o risco de contaminação do alimento. }\end{array}$ & \\
\hline $\begin{array}{l}1.4-\text { As operações de limpeza e, se for o caso, de } \\
\text { desinfecção das instalações e equipamentos, quando não } \\
\text { forem realizadas rotineiramente, são registradas. }\end{array}$ & \\
\hline $\begin{array}{l}1.6 \quad \text { São tomadas precauções para impedir a } \\
\text { contaminação dos alimentos causada por produtos } \\
\text { saneantes, pela suspensão de partículas e pela formação } \\
\text { de aerossóis. Substâncias odorizantes e ou desodorantes } \\
\text { em quaisquer das suas formas não devem ser utilizadas } \\
\text { nas áreas de preparação e armazenamento dos alimentos. }\end{array}$ & \\
\hline $\begin{array}{l}1.9-\text { Os produtos saneantes são identificados e guardados } \\
\text { em local reservado para essa finalidade. }\end{array}$ & \\
\hline $\begin{array}{l}1.10 \text { - Os utensílios e equipamentos utilizados na } \\
\text { higienização são próprios para a atividade e estão } \\
\text { conservados, limpos e disponíveis em número suficiente e } \\
\text { guardados em local reservado para essa finalidade. }\end{array}$ & \\
\hline $\begin{array}{l}1.12 ~-\text { Os funcionários responsáveis pela atividade de } \\
\text { higienização das instalações sanitárias utilizam uniformes } \\
\text { apropriados e diferenciados daqueles utilizados na } \\
\text { manipulação de alimentos. }\end{array}$ & \\
\hline
\end{tabular}

O item 1.1 pode impactar diretamente na qualidade higiênico-sanitária do alimento, podendo causar enfermidades de origem alimentar, devendo ser tomadas as devidas precauções para se evitar tais ocorrências.

Os itens 1,2; 1,6; 1,12 exigem ações corretivas de fácil aplicação, como alguns treinamentos direcionados a práticas de higienização adequadas.

O item 1.4 consiste em uma medida preventiva que servirá como prova em possíveis ocorrências futuras, sendo, portanto, de extrema importância sua implantação. 


\section{CONCLUSÃO}

É possível concluir a partir do estudo realizado que diversos são os produtos utilizados para a limpeza e higienização que podem ser aplicados em etapas diferentes em serviços de alimentação coletiva.

Os responsáveis técnicos encontraram muita dificuldade no início de suas carreiras, para determinar o uso e aplicação de saneantes, pois, conforme mencionado pela maioria, a cadeira que cuida desta disciplina em suas instituições de ensino superior trataram-na de forma superficial, com pouco embasamento teórico e nenhuma atividade prática para auxiliar na fixação do conhecimento.

Alguns estabelecimentos estavam em processo de implantação das boas práticas de fabricação, o que explica algumas das não conformidades relacionadas na discussão. Porém as ações corretivas são simples de serem aplicadas e com o avançar da implantação do manual de boas praticas serão corrigidas. 


\section{REFERÊNCIAS BIBLIOGRÁFICAS}

ANDRADE, J. N.; MACEDO, J. A. B. Higienização na indústria de alimentos. São Paulo, Varela, 1996.

ANDRADE, J. N. Higienização na indústria de alimentos: avaliação e controle de adesão e formação de biofilmes bacterianos. São Paulo, Varela, 2008.

BRASIL, Ministério da Saúde. Agência Nacional de Vigilância Sanitária. ResoluçãoRDC n²16, de 15 de setembro de 2004. Dispõe sobre Regulamento Técnico de Boas Práticas para Serviços de Alimentação

EVANGELISTA, José. Tecnologia de alimentos. São Paulo: Atheneu, 2005

GERMANO, Pedro Manuel Leal; GERMANO, Maria Izabel Simões. Higiene e vigilância sanitária de alimentos. $2^{\mathrm{a}} \mathrm{ed}$. São Paulo: Varela, 2003

MAZZOLA, Priscila Gava; MARTINS, Alzira Maria da Silva; PENNA Thereza Christina Vessoni. Determination of decimal reduction time (d-value) of chemical agents used in hospital disinfection. Brazilian Journal of Microbiology. São Paulo, v.34, p. 33 - 34, out. 2003.

RÊGO, Josedira Carvalho do; FARO, Zelyta Pinheiro de. Manual de limpeza e desinfecção para unidades produtoras de refeições. São Paulo: Varela, 1999

SILVA JUNIOR, Eneo Alves da. Manual de controle higiênico-sanitário em serviços de alimentação. São Paulo: Varela, 2007

SREBERNICH, Silvana Mariana. Utilização do dióxido de cloro e do ácido peracético como substitutos do hipoclorito de sódio na sanitização do cheiro-verde minimamente processado. Ciência e Tecnologia de Alimentos. Campinas, SP, v. 27, n 4, out.-dez., 2007. 


\section{ANEXO 1 - QUESTIONÁRIO SUBJETIVO}

\section{FORMAÇÃO PROFISSIONAL: \\ TEMPO DE EXPERIENCIA PROFISSIONAL:}

Como foi estabelecido o tipo de saneantes a ser utilizado em cada procedimento operacional?

Os conhecimentos prévios sobre os princípios ativos dos saneantes foram suficientes para estabelecer os procedimentos operacionais?

- SIM $\mathrm{NÃO}$

Caso não: Qual a fonte de pesquisa utilizada?

Quais foram os critérios para a seleção dos saneantes estabelecidos nos procedimentos operacionais?

Como foram definidas as freqüências de higienização?

Como foi definida a diluição dos produtos saneantes? 


\section{ANEXO 2 - CHECK LIST HIGIENE}

Check List Higiene - Adaptado de RDC N²16, DE 15 DE SETEMBRO DE 2004.

\begin{tabular}{|l|l|}
\hline FORMAÇÁAO TEMPO DE FORMAÇÁO \\
\hline
\end{tabular}

\begin{tabular}{|c|c|c|c|}
\hline $\begin{array}{l}\text { 1. HIGIENE } \\
\text { UTENSÍLIOS }\end{array}$ & SIM & $\begin{array}{l}\mathbf{N A} \\
\mathbf{O}\end{array}$ & $\begin{array}{l}\text { NÃO } \\
\text { SE } \\
\text { APLIC } \\
\text { A }\end{array}$ \\
\hline \multicolumn{4}{|l|}{$\begin{array}{l}\text { 1.1. As instalações, os equipamentos, os móveis e os utensílios são } \\
\text { mantidos em condições higiênico-sanitárias apropriadas. }\end{array}$} \\
\hline \multicolumn{4}{|l|}{$\begin{array}{l}\text { 1.2. As operações de higienização são realizadas por funcionários } \\
\text { comprovadamente capacitados e com freqüência que garanta a } \\
\text { manutenção dessas condições e minimize o risco de contaminação do } \\
\text { alimento. }\end{array}$} \\
\hline \multicolumn{4}{|l|}{$\begin{array}{l}\text { 1.3. As caixas de gordura são periodicamente limpas. O descarte dos } \\
\text { resíduos atende ao disposto em legislação específica. }\end{array}$} \\
\hline \multicolumn{4}{|l|}{$\begin{array}{l}\text { 1.4. As operações de limpeza e, se for o caso, de desinfecção das } \\
\text { instalações e equipamentos, quando não forem realizadas rotineiramente, } \\
\text { são registradas. }\end{array}$} \\
\hline \multicolumn{4}{|l|}{$\begin{array}{l}\text { 1.5. As áreas de preparação do alimento são higienizada quantas vezes } \\
\text { forem necessárias e imediatamente após o término do trabalho. }\end{array}$} \\
\hline \multicolumn{4}{|l|}{$\begin{array}{l}\text { 1.6. São tomadas precauções para impedir a contaminação dos alimentos } \\
\text { causada por produtos saneantes, pela suspensão de partículas e pela } \\
\text { formação de aerossóis. Substâncias odorizantes e ou desodorantes em } \\
\text { quaisquer das suas formas não devem ser utilizadas nas áreas de } \\
\text { preparação e armazenamento dos alimentos. }\end{array}$} \\
\hline \multicolumn{4}{|l|}{$\begin{array}{l}\text { 1.7. Os produtos saneantes utilizados são regularizados pelo Ministério da } \\
\text { Saúde. }\end{array}$} \\
\hline \multicolumn{4}{|l|}{$\begin{array}{l}\text { 1.8. A diluição, o tempo de contato e modo de uso/aplicação dos produtos } \\
\text { saneantes obedecem às instruções recomendadas pelo fabricante. }\end{array}$} \\
\hline \multicolumn{4}{|l|}{$\begin{array}{l}\text { 1.9. Os produtos saneantes são identificados e guardados em local } \\
\text { reservado para essa finalidade. }\end{array}$} \\
\hline \multicolumn{4}{|l|}{$\begin{array}{l}\text { 1.10. Os utensílios e equipamentos utilizados na higienização são próprios } \\
\text { para a atividade e estão conservados, limpos e disponíveis em número } \\
\text { suficiente e guardados em local reservado para essa finalidade. }\end{array}$} \\
\hline \multicolumn{4}{|l|}{$\begin{array}{l}\text { 1.11. Os utensílios utilizados na higienização de instalações são distintos } \\
\text { daqueles usados para higienização das partes dos equipamentos e } \\
\text { utensílios que entrem em contato com o alimento. }\end{array}$} \\
\hline $\begin{array}{l}\text { 1.12. Os funcionários responsáveis pela atividade de higienização das } \\
\text { instalações sanitárias utilizam uniformes apropriados e diferenciados } \\
\text { daqueles utilizados na manipulação de alimentos. }\end{array}$ & & & \\
\hline
\end{tabular}

\begin{tabular}{|c|c|c|c|}
\hline 2. DOCUMENTAÇÃO E REGISTRO & SIM & NÃO & $\begin{array}{l}\text { NÃO } \\
\text { SE } \\
\text { APLICA }\end{array}$ \\
\hline $\begin{array}{l}\text { 2.1. Os serviços de alimentação dispõem de Manual de Boas Práticas e } \\
\text { de Procedimentos Operacionais Padronizados. Esses documentos estão } \\
\text { acessíveis aos funcionários envolvidos e disponíveis à autoridade } \\
\text { sanitária, quando requerido. }\end{array}$ & & & \\
\hline $\begin{array}{l}\text { 2.2. Os POP contém as instruções seqüenciais das operações e a } \\
\text { freqüência de execução, especificando o nome, o cargo e ou a função } \\
\text { dos responsáveis pelas atividades. São aprovados, datados e assinados } \\
\text { pelo responsável do estabelecimento. }\end{array}$ & & & \\
\hline
\end{tabular}


2.3. Os registros são mantidos por período mínimo de 30 (trinta) dias contados a partir da data de preparação dos alimentos.

2.4. O serviço de alimentação implementa Procedimentos Operacionais Padronizados relacionados aos seguintes itens: a) Higienização de instalações, equipamentos e móveis; b) Controle integrado de vetores e pragas urbanas; c) Higienização do reservatório; d) Higiene e saúde dos manipuladores.

2.5. Os POP referentes às operações de higienização de instalações, equipamentos e móveis contém as seguintes informações: natureza da superfície a ser higienizada, método de higienização, princípio ativo selecionado e sua concentração, tempo de contato dos agentes químicos e ou físicos utilizados na operação de higienização, temperatura e outras informações que se fizerem necessárias. Quando aplicável, os POP contemplam a operação de desmonte dos equipamentos.

2.6. Os POP relacionados ao controle integrado de vetores e pragas urbanas contemplam as medidas preventivas e corretivas destinadas a impedir a atração, o abrigo, o acesso e ou a proliferação de vetores e pragas urbanas. No caso da adoção de controle químico, o estabelecimento apresenta comprovante de execução de serviço fornecido pela empresa especializada contratada, contendo as informações estabelecidas em legislação sanitária específica.

2.7. Os POP referentes à higienização do reservatório especificam as informações constantes POP referentes às operações de higienização de instalações, equipamentos e móveis, mesmo quando realizada por empresa terceirizada e, neste caso, é apresentado o certificado de execução do serviço.

2.8. Os POP relacionados à higiene e saúde dos manipuladores contemplam as etapas, a freqüência e os princípios ativos usados na lavagem e anti-sepsia das mãos dos manipuladores, assim como as medidas adotadas nos casos em que os manipuladores apresentem lesão nas mãos, sintomas de enfermidade ou suspeita de problema de saúde que possa comprometer a qualidade higiênico-sanitária dos alimentos. É especificado os exames aos quais os manipuladores de alimentos são submetidos, bem como a periodicidade de sua execução. O programa de capacitação dos manipuladores em higiene é descrito, e determinada a carga horária, o conteúdo programático e a freqüência de sua realização, mantem-se em arquivo os registros da participação nominal dos funcionários. 